\title{
有限要素法によるダンパー翼周りの気流解析 \\ FINITE ELEMENT ANALYSIS OF AIR FLOW AROUND WINGS OF DAMPERS
}

橋本幸博*, 登坂宣好**

Yukihiro HASHIMOTO and Nobuyoshi TOSAKA

Airflow in air ducts is advection dominant flow where the Reynolds numbers are between $10^{4}$ and $10^{6}$. Flow and pressure fields around wings of dampers in air ducts are obtained numerically at high Reynolds numbers by using Petrov-Galerkin FEM and Multi-pass Algorithm for the unsteady incompressible Navier-Stokes equations. Numerical results of pressure coefficients show good agreements with experimental data for parallel-wing dampers.

Keywords : Duct, Damper, Finite Element Method, Exponential Test Functions,

CFD, Multi-pass Algorithm

ダクト，ダンパー，有限要素法，指数関数型上流化，CFD， Multi-pass Algorithm

\section{1. はじめに}

空調・換気タクト系の設計において、送風機静圧を決定するため に風量調整用ダンパーの抵抗係数を予め知ることは必要なことであ る。ダンパーは、平板を支持軸回りに回転して主流に対する迎角を 付けることにより、タクト系に空気抵抗を付けて風量調節機能を与 える装膡である。長方形ダクト用のダンパーには、1枚翼のものと 多翼のものとがあり、後者には翼の回転方向により、平行翼と対向 翼がある。

従来はダンパーの抵抗係数をタクク設計時点で予測するために、 詳細な実験に基づくテータが必要であった[1][2]|3]。これらの実験では、 タンパー基の枚数や迎角をパラメーターとして抵抗係数を計測する ために、低速風洞に代表される大規模な実験装置と多大な労力が要 求される。

また、タクト系は通常いくつかの枝管に分岐するが、試運転調整 時には各枝管で所定の設計風量が得られるように、ダンパー開度を 調整する。そのときにダンパー翼の後流が偏流を起こすのを防止す るために、ダンパー翼の後流の状態を予測することが必要である。 タクト内気流が偏流を起こすと、ダンパーの下流に設置した吹出口
から均一な吹出風量が得られず室内温度分布が不均一になるという 問題を起こすことがある|[1]。また、ダンパー翼の迎角やタクト内気流 速度によっては、翼表面から剥離した流れによる気流騷音や、周期 的な揚力変動による翼の振動が発生する。そのような騒音や振動が 居室に伝播することにより、室内環境を阻害する原因となる。従っ て、室内温度分布やダンパー翼から発生する気流騒音及び振動を設 計時点で事前評価するためには、ダンパー翼周りの気流性状に関す る知識が不可欠である。

通常タクト内部の気流性状を把握するために、気流の可梘化が行 われる。従来の実験的なダクト内気流の可梘化手法には、タフト法、 トレーサー法、光学的方法などがある(5||6]。空調・換気タクト内部の 気流速度は 5〜 $10 \mathrm{~m} / \mathrm{sec}$ 程度であり、いずれの方法を用いても実䀦手 法、撮影技術、画像処理などに高度な熟練技術や多大なコストが必 要になるという問題がある。

最近は計算機性能の向上に従って、CF Dによるアプローチも可 能になってきたため、数值風洞として実験に代わるダクト内気流の 性状把握が有望視されている。CF Dはパラメトリックな流れの可 視化が比較的簡便で安価にできるという利点があり、実臨による労

* 東洋熟工業侏技術研究所

** 日本大学生産工学部数理工学科 教授·工博 
カや熟練技術やイニシャル・コストを削減できる。また、ダクト内 部は狭险な空間であり、実験的手法ではセンサーやワイアなどを挿 入することにより、流れ場に影第を与える危険性があるが、C F D を用いればこの危険を回避することができる。ダンパー翼周りの気 流解析をするときには、解析領域が複雑形状になるので、非構造格 子を用いた有限要素法による解析が有効である。

ところで、ダクト内部の気流はレイノルズ数がおよそ $10^{4} \sim 10^{6}$ の 移流卓越流れであるが、このような高レイノルズ数流れを数值計算 するときには、圧力解が数值振動を起こしやすいということが知ら れている。数值振動を抑えるために、差分法では今までに様々な上 流化手法が考えられてきたが、有限要素法でも様々な上流化手法が 提宋され、高レイノルズ数流れを安定的に数值解析することができ るようになった[7]。通常流れ解析で用いられる有限要素法は、 Galerkin 法と呼ばれる手法で、解析領域を有限要素に分割し、補間 関数と同一の関数をテスト関数に用いて、得られた積分方程式を 近似的に解く方法である。それに対して、Petrov-Galerkin 法は、㭪 間関数とは異なる上流化されたテスト関数を用いて近似解析する方 法である[8]。

空調ダクト内部の気流性状の把握は重要であるにも関わらず、 C F Dによるタクト内気流解析に関する文献は、著者らが知る限り ではほとんどない。そこで、本報では形状適合性に優れた有限要素 法を用い、計算の安定化のために指数関数型上流化テスト関数 ${ }^{[8]}$ を用 いて、タクト内部のタンパー翼周りの気流を数值解析した結果を報 告する。

以下の定式化に当たり、記号(,)と只はそれぞれ空間及び時間変 数に関する偏微分を表し、また指標については Einstein の総和規約 を採るものとする。

\section{2. 有限要素法による定式化}

無次元化された以下の 2 次元非定常非圧縮性 Navier-Stokes 方程 式と連綂の式を基礎方程式とする。

$$
\begin{gathered}
\dot{u}_{i}+u_{j} u_{i, j}=-p_{, i}+\frac{1}{\operatorname{Re}} u_{i, j j} \\
u_{i, i}=0
\end{gathered}
$$

ここで、 $u_{i}(i=1,2)$ は空間 2 方向の流体の速度、 $p$ は圧力、Re は レイノルズ数である。レイノルズ数は慣性力と粘性力の比を表す無 次元数で、 $\mathrm{Re}=\frac{u D}{v} 、 \mathrm{u}$ は代表速度、D は代表長さ、 $\nu$ は動粘性釈 数である。

式(1)に対し fractional-step 分解を用いて速度と圧力を分離し、時 間について半離散表現をすると次式を得る。

$$
\text { First Step }: \frac{\bar{u}_{i}-u_{i}^{n}}{\Delta t}+u_{j}^{n} u_{i, j}^{n}=\frac{1}{\operatorname{Re}} u_{i, j j}^{n}
$$

Second Step : $u_{i}^{n+1}=\bar{u}_{i}-\Delta t p_{, i}^{n+1}, u_{i, i}^{n+1}=0$

ただし、 $\Delta t$ は時間ステップ、 $\bar{u}$ は修正速度である。
ここで、修正速度ポテンシャル $\phi=-\Delta t \cdot p^{n+1}$ を用いると、式(4) は次式のようになる。

$$
u_{i}^{n+1}=\bar{u}_{i}+\phi_{, i}
$$

更に式(5)の発散をとり、連繶の式を用いると $\phi に$ 関する次の Poisson 方程式が得られる。

$$
\phi_{, i i}=-\bar{u}_{i, i}
$$

式(6)を対応する境界条件のもとで解き、得られた $\phi$ を用いて、次 ステップの圧力と速度を求める。

ここで、式(3)に対し、指数関数型上流化関数 $M_{\alpha}$ をテスト関数に 用いて、Petrov-Galerkin 法により重み付き残差方程式を構成する。 なお要素には 4 角形要素を用い、速度・圧力同次補間の双 1 次補間 関数 $N_{\alpha}$ を用いる。

$$
\begin{gathered}
\int_{\Omega_{i}}\left\{\frac{\bar{u}_{i}-u_{i}^{n}}{\Delta t}+u_{j} u_{i, j}-\frac{1}{\operatorname{Re}} u_{i, j j}\right\} M_{\alpha} d \Omega=0 \\
M_{\alpha}=N_{\alpha} e^{-a_{i}\left(N_{r} x_{i}^{\gamma}-x_{i}^{\alpha}\right)}, i=1,2
\end{gathered}
$$

ここで、 $a_{i}$ は次式によって与えられる。

$$
a_{i}=\frac{\alpha_{i}}{\left|L_{i}\right|} \operatorname{sgn}\left(u_{i}\right), i=1,2
$$

ただし、 $\alpha_{i}$ は人工粘性係数に対応するスケーリング・パラメーター、 sgn は符号関数 (signum function) である。

得られた式の時間積分に 2 次精度 Adams-Bashforth 法を用いて、

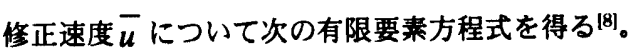

$$
\begin{gathered}
M_{\alpha \beta} \frac{\left\{\bar{\mu}_{i}\right\}_{\beta}-\left\{\mu_{i}^{n}\right\}_{\beta}}{\Delta t}=\frac{3}{2} f_{a}^{n}-\frac{1}{2} f_{a}^{n-1} \\
\left.\left.f_{a}^{n}=-K_{\alpha \beta}\left(u_{j}^{n}\right\}_{\mu_{i}{ }^{n}}\right\}_{\beta}+F_{\alpha \beta} \tilde{\tau}_{i}{ }^{n}\right\}_{\beta}
\end{gathered}
$$

ここで、 $M_{\alpha \beta}$ は質量行列、 $F_{\alpha \beta}$ は境界積分項、 $\tilde{\tau}_{i}^{n}=u_{i, j}^{n} n_{j} / \mathrm{Re}$ 、 $\Delta t$ は時間間隔、nは時間ステップ数である。また、式(10)を次のよ うに書き改める。

$$
M_{\alpha \beta} \Phi_{\beta}=\Delta t\left(\frac{3}{2} f_{\alpha}^{n}-\frac{1}{2} f_{\alpha}^{n-1}\right)
$$

式(11)の計算をするときに、逆行列の計算を避けて、陶的に郡算 を行うために兵量行列の対角化がよく行われる。ここでは、対角化 による誤差を避けるために J. Donea らによって提案された MultiPass Algorithm ${ }^{[\theta \mid}$ 用いる。その考え方は次の通りである

$$
\bar{M}_{\alpha \beta} \Phi_{\beta}^{(k)}=\Delta t\left(\frac{3}{2} f_{a}^{n}-\frac{1}{2} f_{a}^{n-1}\right)-\left(M_{\alpha \beta}-\bar{M}_{\alpha \beta}\right) \Phi_{\beta}^{(k-1)}
$$

ここで、 $\bar{M}_{\alpha \beta}$ は集中暂要行列であり、 $\Phi_{\beta}=\left\{\bar{u}_{i}\right\}_{\beta}-\left\{u_{i}\right\}_{\beta}^{n} \cdot \Phi_{\beta}^{(k) 及 ひ ゙ ~}$

$\Phi_{\beta}^{(k-1)}$ は未知である。 

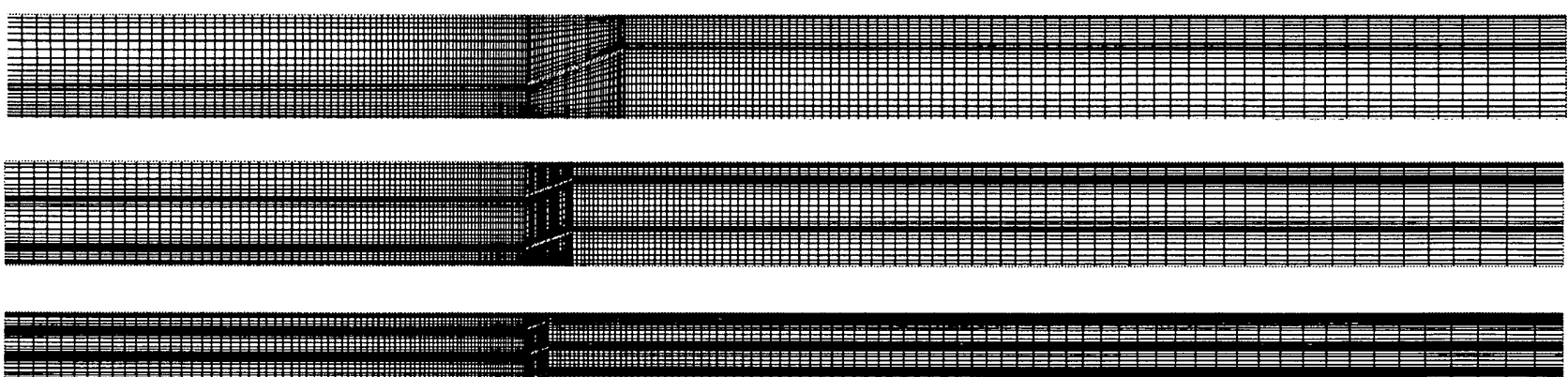

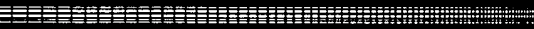
年

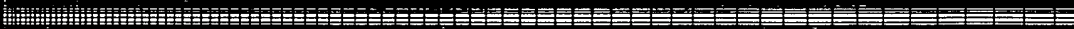

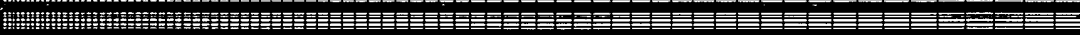

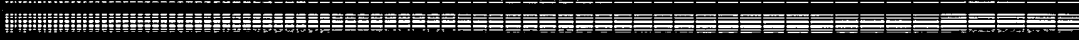

Fig. 1 Finite Element Mesh $\left(1,2,4\right.$ Wing Attack Angle $\left.=20^{\circ}\right)$

$k=1$ とおくと

$$
\bar{M}_{\alpha \beta} \Phi_{\beta}^{(1)}=\Delta t\left(\frac{3}{2} f_{\alpha}^{n}-\frac{1}{2} f_{\alpha}^{n-1}\right)-\left(M_{\alpha \beta}-\bar{M}_{\alpha \beta}\right) \Phi_{\beta}^{(0)}
$$

ここで、 $\Phi_{\beta}^{(0)}=0$ とおくと、

$$
\bar{M}_{\alpha \beta} \Phi_{\beta}^{(1)}=\Delta t\left(\frac{3}{2} f_{\alpha}^{n}-\frac{1}{2} f_{a}^{n-1}\right)
$$

となる。 $k=2,3$ とおくと、

$$
\begin{aligned}
& \bar{M}_{\alpha \beta} \Phi_{\beta}^{(2)}=\Delta t\left(\frac{3}{2} f_{a}^{n}-\frac{1}{2} f_{\alpha}^{n-1}\right)-\left(M_{\alpha \beta}-\bar{M}_{\alpha \beta}\right) \Phi_{\beta}^{(1)} \\
& \bar{M}_{\alpha \beta} \Phi_{\beta}^{(3)}=\Delta t\left(\frac{3}{2} f_{a}^{n}-\frac{1}{2} f_{a}^{n-1}\right)-\left(M_{\alpha \beta}-\bar{M}_{\alpha \beta}\right) \Phi_{\beta}^{(2)}
\end{aligned}
$$

ここで、

$$
\Phi_{\beta}^{(3)}=\left\{\boldsymbol{u}_{i}\right\}_{\beta}-\left\{u_{i}\right\}_{\beta}^{n}
$$

より、全体系の修正速度は

$$
\bar{u}_{i}=u_{i}^{n}+\Phi^{(3)}
$$

となる。以上の 3-pass による Multi-pass algorithm によって修正速

度 $\bar{u}_{i}$ を求め、式(6)で与えられた $\phi$ を定める Poisson 方程式を解く。 Poisson 方程式の計算には、SCG 法（前処理付共役勾配法）を用い る。そして、次ステップの圧カ $p^{n+1}$ と速度 $u_{i}^{n+1}$ を求め、時間積 分を進める。

\section{3. 数值計算結果}

ダクト内に平行翼ダンパーを設直し、翼の迎角をパラメーターと して、下記の計算条件に基づく数值計算を行う。

【計算条件】

解析領域： $15.0 \times 1.0$ (2 次元)

要素：4 角形双 1 次要素

境界条件： ダクト内面とダンパー表面 Non-Slip 流入部 $u=1.0$ 、流出部 $\phi=0$ (Dirichlet 条件)

ダンパーの翼の枚数 : 1 枚、 2 枚、 4 枚

翼の厚さ： 0.01

翼の迎角： $5 、 10 、 15 、 20 、 30^{\circ}$

レイノルズ数 : $10^{4}$

Poisson 方程式の反復回数 : 最大 1000 回
スケーリング・パラメーター： 0.2

時間積分法 : 2 次精度 Adams-Bashforth 法

無次元時間刻み: $\Delta t=5 \times 10^{-4}$

時間ステップ : 40000 ステップ

無次元時間 : $t=20$

\begin{tabular}{|c|c|c|c|}
\hline & 1 枚翼 & 2 枚翼 & 4 枚翼 \\
\hline 翼の長さ & 1.0 & 0.5 & 0.25 \\
\hline 総節点数 & 6834 & 7035 & 10317 \\
\hline 総要素数 & 6560 & 6720 & 10000 \\
\hline $\begin{array}{c}\text { 最小メッシュ幅 } \\
\text { (翼角度 } 30^{\circ} \text { のとき }\end{array}$ & 0.009492 & 0.008449 & 0.004752 \\
\hline クーラン数 & 0.0526 & 0.0592 & 0.1052 \\
\hline
\end{tabular}

Fig.1 に解析領域の有限要素分割を示し、Fig.2 から 4 に無次元時 間 $\mathrm{t}=20$ における計算結果を示す。

\section{4. 考察}

\section{1 計算結果と実測との比較}

無次元時間 $\mathrm{t}=5$ から 20 まで時間平均した抵抗係数と実測結果の比 較を表 1 に示す。抵抗係数 $\mathrm{K}$ は次式にて算出する。

$$
K=\frac{2 \Delta p}{\rho U^{2}}
$$

ただし、 $\Delta p$ はダンパー翼前後の圧力差、 $\rho$ は流体の密度 $(=1.0)$ 、 U は初速（=1.0）である。

実測結果は、文献[1]で妥当な抵抗係数であると評価されている Erwin-Idelchik による結果を採用している。2枚翼ダンパーの迎角 が $10^{\circ}$ のときを除いて実測值に対して $\pm 20 \%$ 以内の誤差であり、実 用上問題ない程度に一致している。

文献[1] の Erwin-Idelchik の推奖値では、翼の角度が $10^{\circ}$ のとき を除いて、翼の枚数を増やすと抵抗倸数が減少している。文献[1]に よる計算値では、 2 枚翼の $10^{\circ}$ のときの抵抗係数は 0.33 となってい て、1枚翼のときより減少している。また、文献[3]では、 2 枚翼の $10^{\circ}$ のときの抵抗係数は 0.17 となっている。また、翼の枚数が増加 すると、抵抗係数が减少するという傾向に、迎角が 10 ののときのみ 特異性があるとは考えられない。

2 翼 $10^{\circ}$ のとき抵抗係数は 0.2 近傍で安定しているが、揚力係数 はカルマン渦に起因する大きい変化を見せている。本計算では、タ ンパー翼を剛体と見なしているが、実際はダクト側面に回転軸で支 持された構造の両端支持梁で弾性体である。このモテルの相違が抵 抗係数の大きな差の原因になっているものと推定される。 


\section{2 圧力の最大值と最小值}

Fig.5 に $\mathrm{t}=20$ におけるダクト内部圧力の最大値と最小値を、タン パー頨角度 10、20、30 について示す。ダンパー翼角度が增加する に伴い、いずれの埸合も圧力の最大值は増加し、最小値は減少する。 また、タンパー頨枚数が増加するに伴い、最大値は堿少するが、最 小值は 2 枚のときが最低となる。

\section{3 抵抗係数の变動}

Table 2 に抵抗係数の計算俌（無次元時問 5 から 20 まで） 3000 個のデータの RMS(Root Mean Square)を示す。ダンパー頨角度が増 加するに伴い RMS は增加し、枚数が增加するに伴い RMS が娍 少することがわかる。

Table 3 に圧力係数の平均変功率を示す。これは、圧力係数の RMS 值を平均値で割った值である。1 枚置のときは翼の迎角が增加するに 伴い平均变動事は減少する。2 及び 4 枚翼のときは迎角が $10^{\circ}$ のとき より $20^{\circ}$ と $30^{\circ}$ の方が平均変動率は增加するが、 $20^{\circ}$ と $30^{\circ}$ ではほ とんど同じである。

Fig.2から4のように翼の上面では首流状熊で気流が流れ、特に迎 角が 10 ・以上になると翼の下面で流れが激しく变動している。基の 下面では剥噰した流れが瀜を形成し、㣪流に瀜列が放出されて いる。ダンパー翼角度が増加すると、またダンパーの资長が長くな ると剥離が促進されるため、圧力保数の変動が大きくなる。

空調ダクトのダンパー翼や空調吹出口から発生する風切音が問題 になることがあるが、これは固体の振動ではなく、気流自体から発 生する騷音で空気力学的な騒音と呼ばれる ${ }^{133}$ 。Fig.2から 4 で見られ ろカルマン瀜列の放出は、時間的な圧力変動となり、空力搔音の原 因になるものと予想される。

Table1. Comparison of Calculated and Measured Pressure Coefficients

(a) 1 Wing

\begin{tabular}{|c|c|c|c|}
\hline Attack Angle & Calculated & Measured $^{[1]}$ & Error Rate \\
\hline $10^{\circ}$ & 0.35 & 0.35 & $0 \%$ \\
\hline $20^{\circ}$ & 1.30 & 1.25 & $4 \%$ \\
\hline $30^{\circ}$ & 3.36 & 3.60 & $-6 \%$ \\
\hline
\end{tabular}

(b) 2 Wings

\begin{tabular}{|c|c|c|c|}
\hline Attack Angle & Calculated & Measured $^{\text {III }}$ & Error Rate \\
\hline $10^{\circ}$ & 0.20 & 0.40 & $-50 \%$ \\
\hline $20^{\circ}$ & 0.89 & 1.10 & $19 \%$ \\
\hline $30^{\circ}$ & 2.07 & 2.20 & $-6 \%$ \\
\hline
\end{tabular}

(c) 4 Wings

\begin{tabular}{|c|c|c|c|}
\hline Attack Angle & Calculated & Measured $^{\text {III }}$ & Error Rate \\
\hline $10^{\circ}$ & 0.18 & 0.22 & $-18 \%$ \\
\hline $20^{\circ}$ & 0.67 & 0.73 & $8 \%$ \\
\hline $30^{\circ}$ & 1.54 & 1.50 & $3 \%$ \\
\hline
\end{tabular}

Table 2. RMSs of Calculated Pressure Coefficients

\begin{tabular}{|c|c|c|c|}
\hline Attack Angle & 1 Wing & 2 Wings & 4 Wings \\
\hline $10^{\circ}$ & 0.311 & 0.019 & 0.005 \\
\hline $20^{\circ}$ & 0.592 & 0.143 & 0.083 \\
\hline $30^{\circ}$ & 1.188 & 0.334 & 0.171 \\
\hline
\end{tabular}

Table 3. The Magnitude of Fluctuations

in Calculated Pressure Coefficients

\begin{tabular}{|c|c|c|c|}
\hline Attack Angle & 1 Wing & 2 Wings & 4 Wings \\
\hline $10^{\circ}$ & $89 \%$ & $10 \%$ & $3 \%$ \\
\hline $20^{\circ}$ & $46 \%$ & $16 \%$ & $14 \%$ \\
\hline $30^{\circ}$ & $35 \%$ & $16 \%$ & $11 \%$ \\
\hline
\end{tabular}

Table 4. Nominal Strouhal Numbers of the Flow Fields

\begin{tabular}{|c|c|c|c|}
\hline Attack Angle & 1 Wing & 2 Wings & 4 Wings \\
\hline $10^{\circ}$ & 0.20 & 0.29 & 0.29 \\
\hline $20^{\circ}$ & 0.34 & 0.48 & 0.48 \\
\hline $30^{\circ}$ & 0.49 & 0.68 & 0.63 \\
\hline
\end{tabular}

Table5 Actual Strouhal Numbers

\begin{tabular}{|c|c|c|c|}
\hline Attack Angle & 1 Wing & 2 Wings & 4 Wings \\
\hline $10^{\circ}$ & 0.17 & 0.25 & 0.24 \\
\hline $20^{\circ}$ & 0.22 & 0.32 & 0.32 \\
\hline $30^{\circ}$ & 0.25 & 0.34 & 0.32 \\
\hline
\end{tabular}

Table 6. The Magnitude of Fluctuations in Calculated Lift Coefficients

\begin{tabular}{|c|c|c|c|}
\hline Attack Angle & 1 Wing & 2 Wings & 4 Wings \\
\hline $10^{\circ}$ & $43 \%$ & $13 \%$ & $5 \%$ \\
\hline $20^{\circ}$ & $33 \%$ & $20 \%$ & $18 \%$ \\
\hline $30^{\circ}$ & $39 \%$ & $20 \%$ & $14 \%$ \\
\hline
\end{tabular}

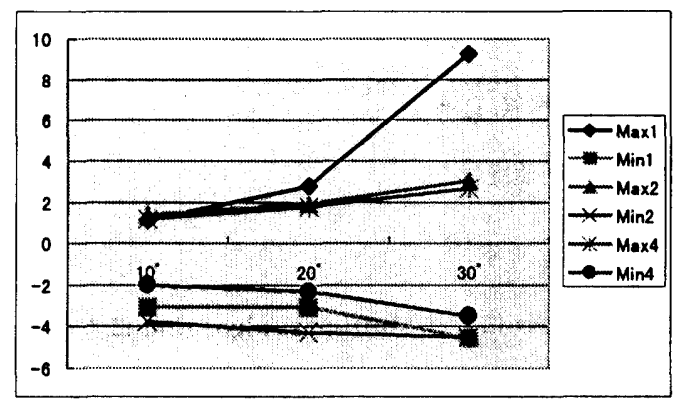

Fig. 5 Maximum and Minimum Pressure at $\mathrm{t}=20$

\section{4 ストローハル数の比較}

Table4 に、流れのストローハル数を示す。ストローハル数は、 $S t=f D / u$ で表される無次元数で、流れの中に置かれた物体が放 出するカルマン瀜の無次元周波数を表す[12]。ただし、f はカルマン洞 発生周波数、Dはダクト幅（=1.0）、 u は初期流速（=1.0）である。

ストローハル数は、低マッハ数では形状によって変わるレイノル ズ数の関数である。これを算出するために、揚力の時間変動データ から FFT（高速フーリエ変換）により揚力変動の卓越周波数 $f$ を求 めた。Table4 から、ダンパー翼の迎角が増加するに伴い、ストロー ハル数が大きくなることがわかる。但し、ここで用いた流速は初期 流速 $\mathrm{u}=1.0$ であり、ダンパー翼の迎角の增加でダクト内流路が閉塞 したことによる正味流速で計算すると、Table5 のように、ストロー ハル数は 1 枚習で $0.17 〜 0.25 、 2$ 及び 4 枚翼で $0.25 \sim 0.34$ であるこ とがわかる。表面が滑らかな静止円柱では、レイノルズ数が 500 以 上では $\mathrm{St}=0.21$ である。その他の形状についても、ストローハル数 はこの近傍の値である。 


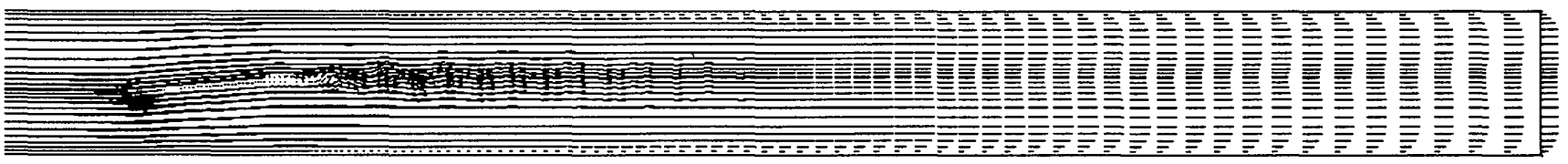

(a)

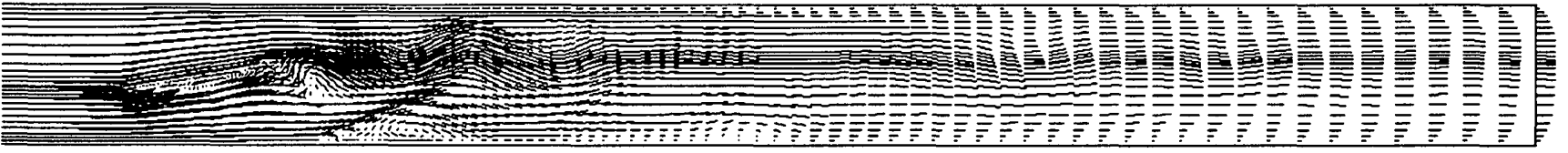

(b)

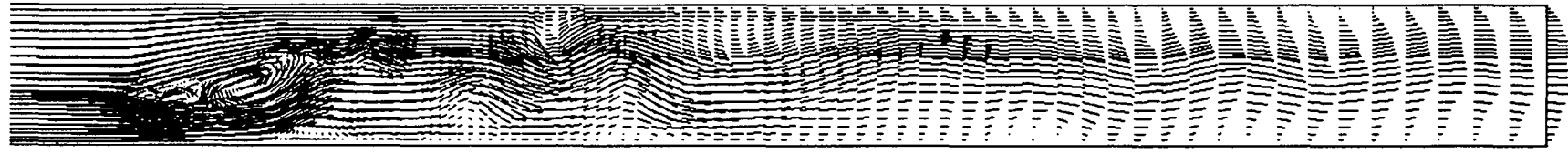

(c)

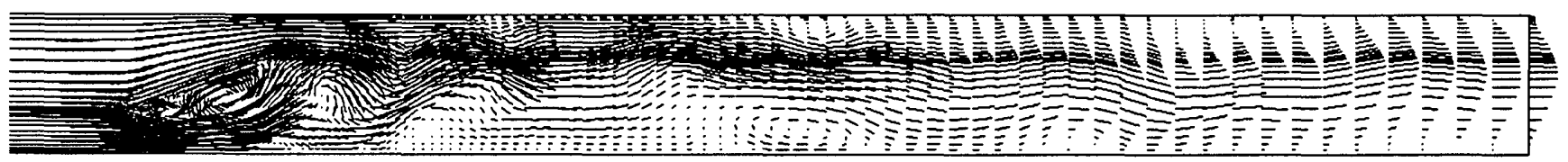

(d)

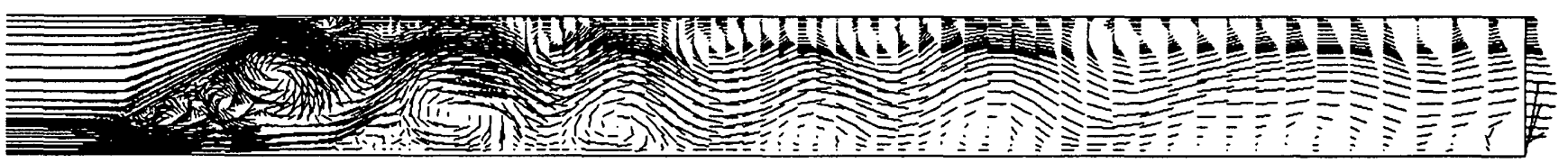

(e)

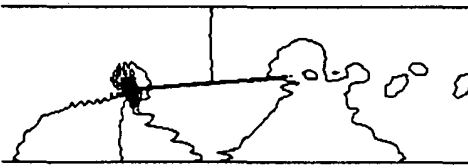

(a)
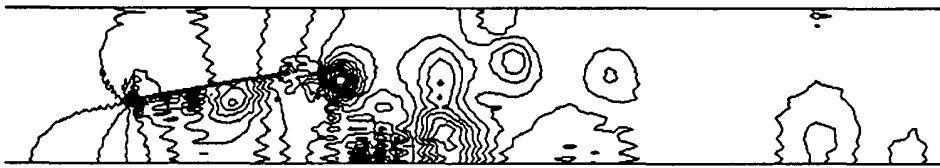

(0)

(b)
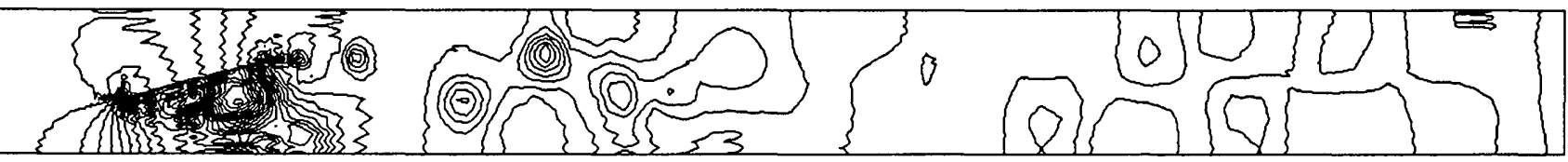

(c)

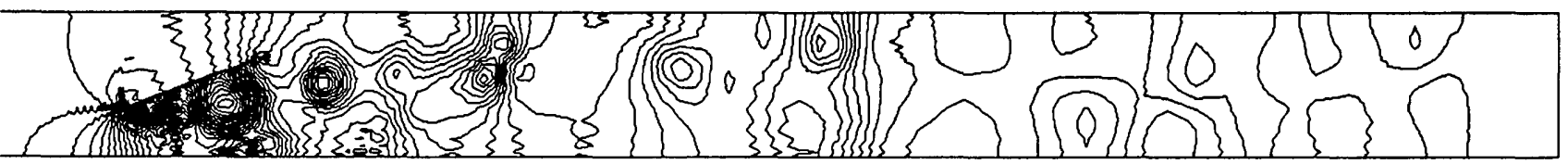

(d)

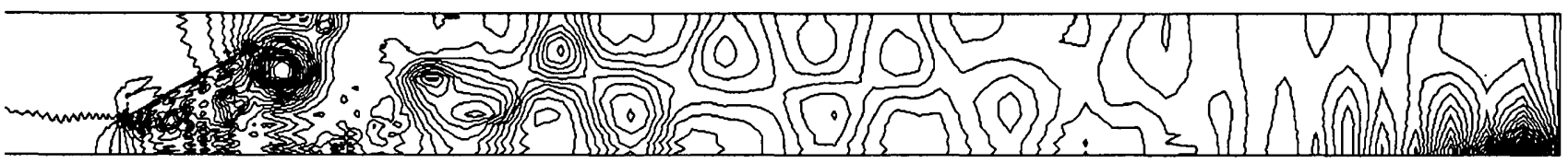

(e)

Fig.2 Velocity Vectors and Pressure Contours (1 Wing $R e=10^{4}$ ) (Attack Angle : $\theta$ )
(a) $\theta=5^{\circ}$
(b) $\theta=10^{\circ}$
(c) $\theta=15^{\circ}$
(d) $\theta=20^{\circ}$
(e) $\theta=30^{\circ}$ 


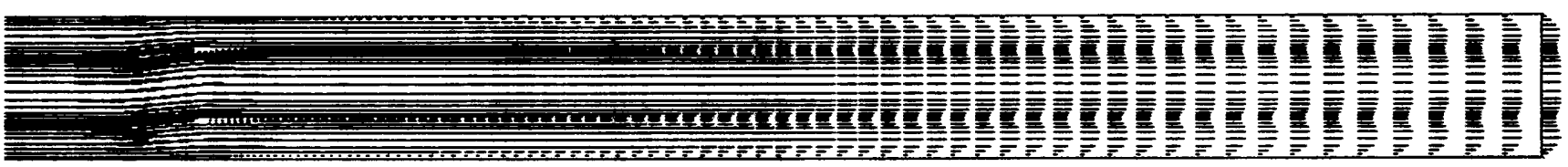

(a)

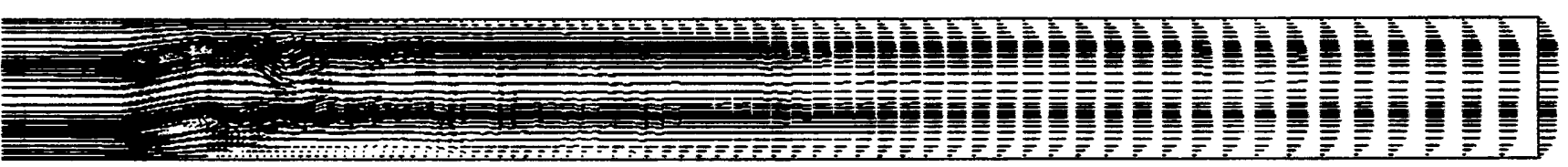

(b)

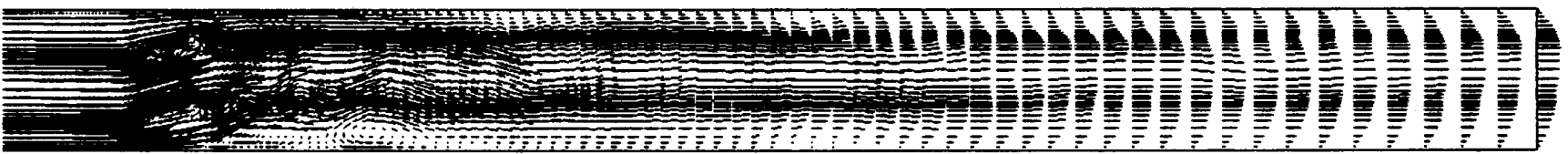

(c)

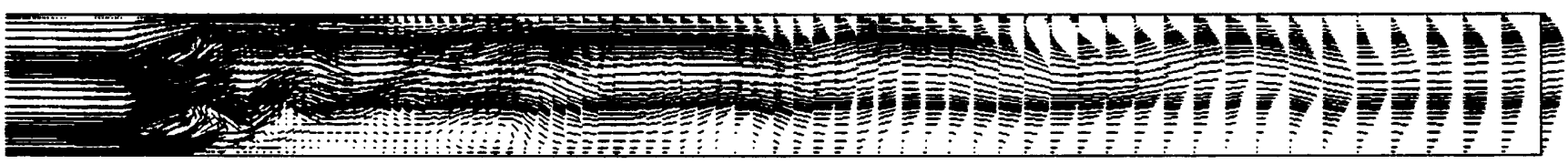

(d)

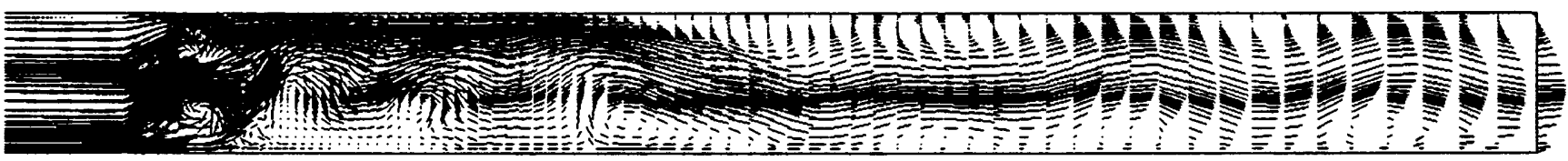

(e)

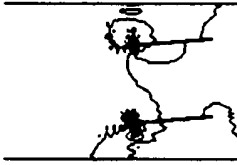

(a)

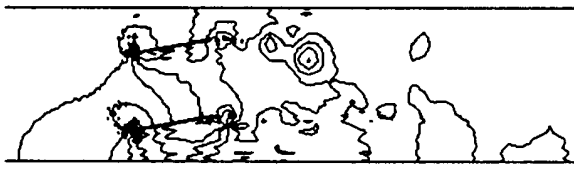

(b)

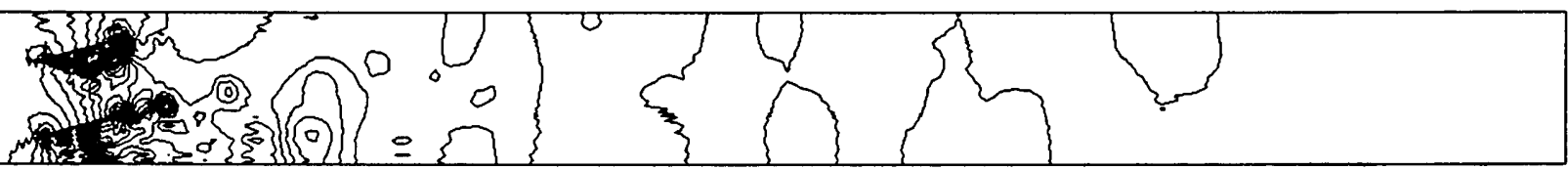

(c)

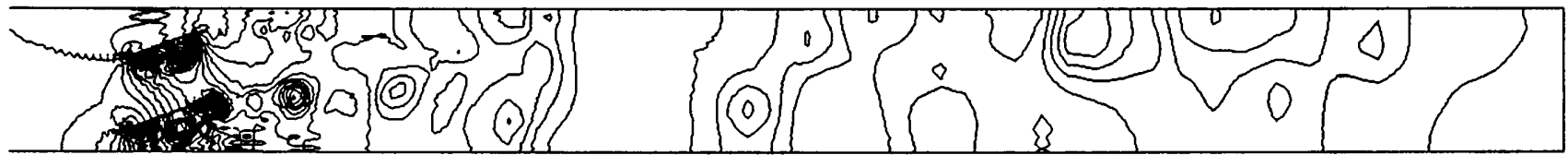

(d)

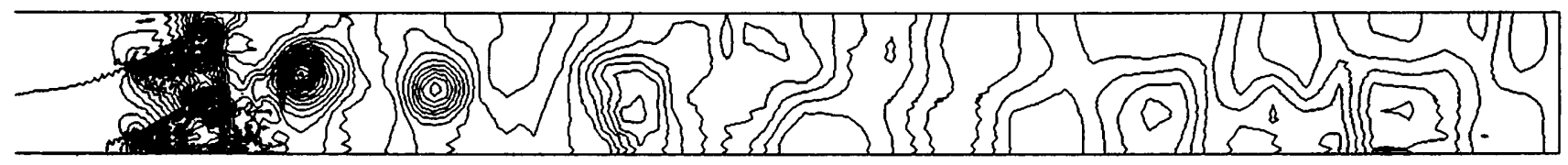

(e)

Fig.3 Velocity Vectors and Pressure Contours (2 Wings $R e=10^{4}$ ) (Attack Angle : $\theta$ )
(a) $\theta=5^{\circ}$
(b) $\theta=10^{\circ}$
(c) $\theta=15^{\circ}$
(d) $\theta=20^{\circ}$
(e) $\theta=30^{\circ}$ 


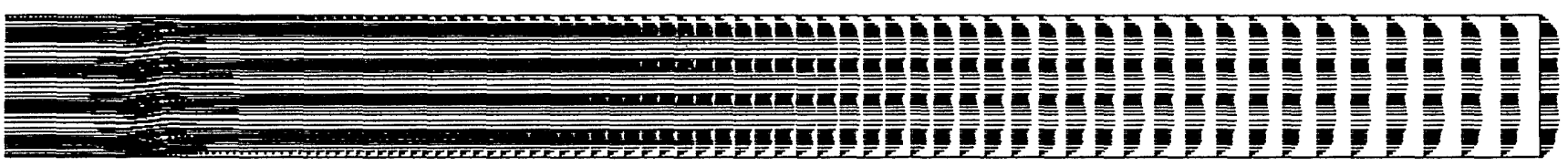

(a)

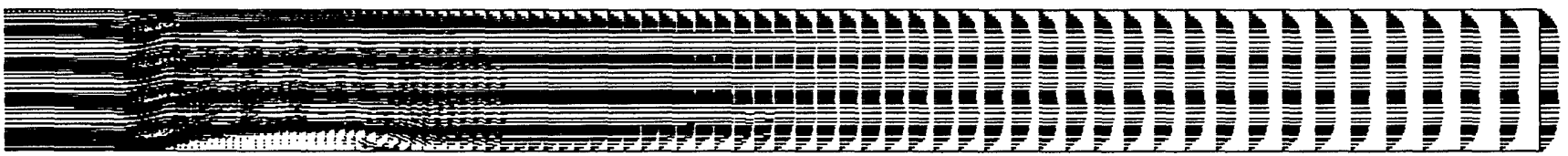

(b)

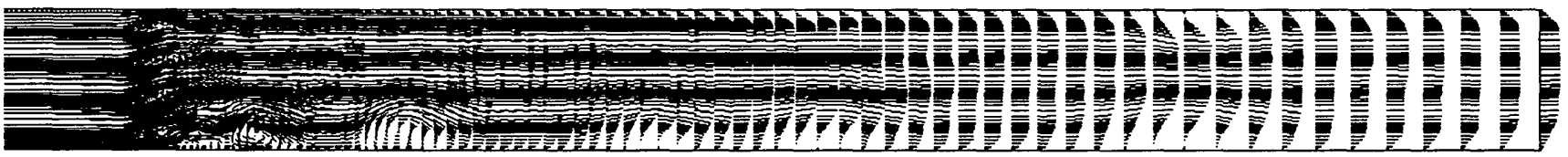

(c)

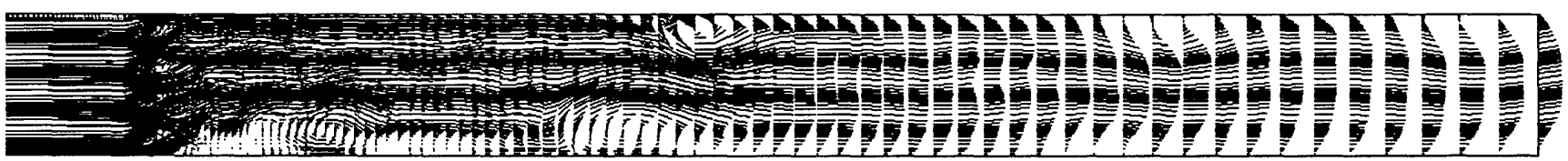

(d)

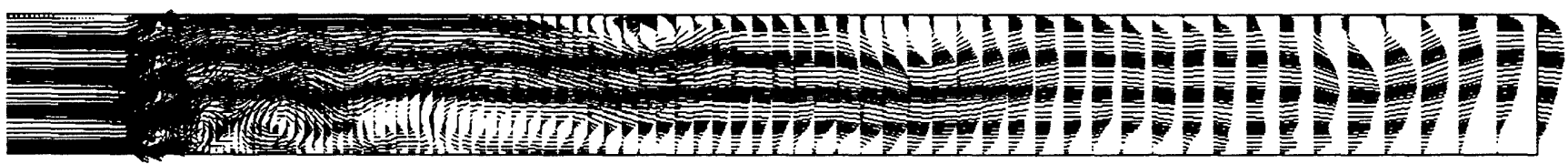

(e)

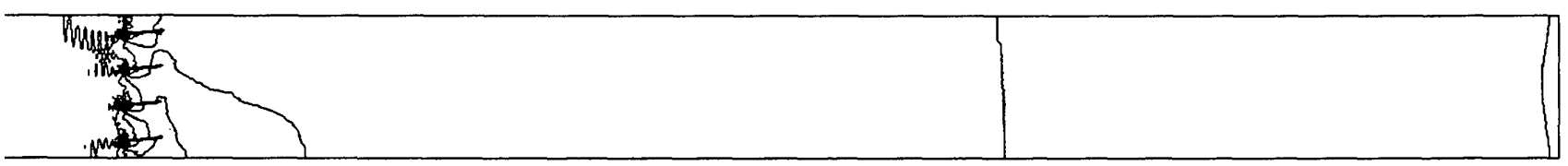

(a)

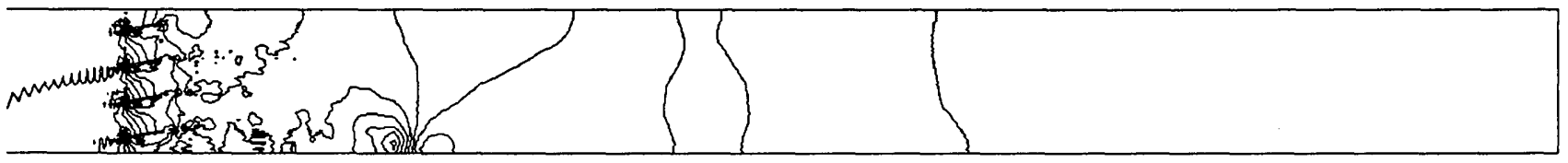

(b)

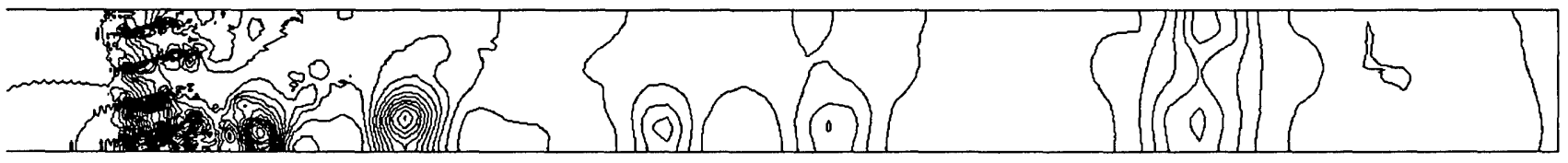

(c)

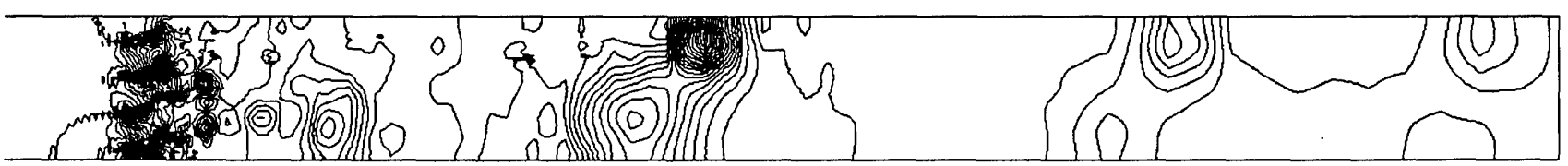

(d)

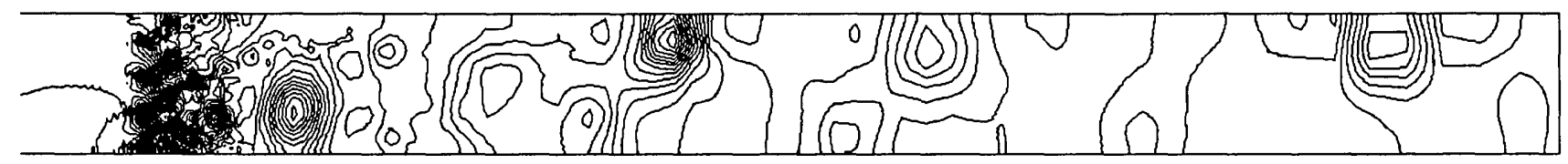

(e)

Fig.4 Velocity Vectors and Pressure Contours (4 Wings $R e=10^{4}$ ) (Attack Angle : $\theta$ )
(a) $\theta=5^{\circ}$
(b) $\theta=10^{\circ}$
(c) $\theta=15^{\circ}$
(d) $\theta=20^{\circ}$
(e) $\theta=30^{\circ}$ 
ストローハル数の逆数を換算流速と呼ぶが、文献[14]によれば、こ の换算流速が 6 程度で揚力変功は最大になる。Table3で 1 枚翼ダン パーの迎角が $10^{\circ}$ のとき、抵抗係数の変勤率が最大になっているが、 Table6 に示すように揚力変動もこのときが最大である。このときの 換算流速は、Table5 に示す正味流速から求めたストローハル数から 算出すると的 6 であり、実際の現象が本解析により再現されている ことがわかる。

\section{5. まとめ}

1,2,4 枚平行琵タンパー周りの気流を、非構造格子を用い、 Multi-Pass Algorithm による有限要来法解析した結果、次の知見を得 た。これらは、本手法による平行頨タンパーの周りの 2 次元居流 解析が有効であることを示している。

（1）抵抗俰数の計算値の時間平均は、実測結果と比較的よい一 致を示した。

（2）ダクト内部の圧力の最大值は、ダンパー翼枚数が堌加する に伴い娍少するが、最小値は2枚理のときが最低になる。

（3）抵抗保数の計算值の無次元時間 5 から 20 までの RMS は、 ダンパー頊の迎角が増加するに伴い増加し、翼の枚数が鲑 加するに伴い減少する。

（4） カルマン瀜放出のストローハル数は、正味流速で算出する と 1 枚翼のとき 0.17 から $0.25 、 2$ 及び 4 枚頨のとき 0.25 から 0.34 である。

（5）換睢流速が約 6 のとき、抵抗俰数の㚆動率及び揚力㚆動が 最大になる。これは実際の現象と一致する。

\section{it 辞}

本論文における数値計算を実行するに際し、スキームに関して日本 大学生産工学部数理工学科角田和彦助教授、アルゴリズムに開して 同大学院博士後期課程三浦慎一郎氏から有益な助言を頂くことがで きたことに深く楋意を表す。

\section{【参考文献】}

[1]五十嵐保、長方形ダクト内平行翼ダンパの抵抗係数、日本機珹学 会論文集 \{B編\} 61 巻 589 号 (1995-9)

[2]五十嵐保、平行翼ダンパの抵抗係数に及ぼす羽根数および羽根角 度の影需、日本機械学会馀文集 \{B編\}63 卷606 号 (1997-2)

[3]日本機珹学会、技術資料、管路・ダクトの流体抵抗、丸普（1979） [4]可梘化情報学入門編集委員会編、可視化情報学入門、東京電機大 学出版局（1994）

[5]可視化情報学会編、流れの可視化入門、朝會書店（1996）

[6]空気調和 - 得生工学会編、空気㷙和 - 衛生工学便筧第 12 版、空気 調和・衛生工学会（1995）

[7]登坂宣好、有限要秦法における風上化スキーム、充用数理、 Vol.7,No.2,1997-6

[8]角田和彦、登坂宣好: 非定常非圧縮性流九の指数関数型 PetrovGalerkin 有限要素法,日本建築学会楼造系綸文報告集第 439 号, 1992 年 9 月

[9] J. Donea, S. Giuliani, H. Laval, Time-accurate solution of advection-diffusion problems by finite elements, Computer Methods in Applied Mechanics and Engineering 45(1984)

[10] 橋本、登坂、角田、三浦、Multi-Pass Algorithm による非任管 性流体の有限要秦法解析、第 11 回数值流体力学シンボジウム講演 論文集（1997 年 12 月）

[11]佣橋隆彦、C F D - 数值流体力学、アイピーシー（1993）

[12]江守一郎、模型実験の理論と応用、技報堂出版（1985）

[13]M.J.Lighthill, On Sound Generated Aerodynamically, I. General Theory, Proc. Roy. Soc. Lon., A211(1952)

[14]日本流体力学会編、流体力学ハンドブック第 2 版、丸普(1998)

（1998年 7 月 7 日原稿受理，1998年11月 12 日採用決定） 